\title{
ANTIBACTERIAL ACTIVITY OF THE ETHANOLIC EXTRACTS DERIVED FROM LEAVES AND PSEUDOBULBS OF SOME ORCHIDS BELONGING TO COELOGYNE GENUS AGAINST ENTEROBACTER CLOACAE STRAIN
}

\author{
Buyun Lyudmyla ${ }^{1}$, Tkachenko Halyna*2 ${ }^{2}$ Kurhaluk Natalia ${ }^{2}$, \\ Gyrenko Oleksandr ${ }^{1}$, Kovalska Lyudmyla ${ }^{1}$, Góralczyk Anna ${ }^{2}$, \\ Tomin Vladimir ${ }^{3}$, Osadowski Zbigniew ${ }^{2}$ \\ ${ }^{1}$ M.M. Gryshko National Botanic Garden, National Academy of Science of Ukraine, Kyiv, Ukraine
${ }^{2}$ Institute of Biology and Earth Sciences, Pomeranian University in Słupsk, Poland
${ }^{3}$ Department of Physics, Pomeranian University in Słupsk, Poland
}

Received: 15. 11. 2019 Revised: 4. 12.2019 Published: 6. 12. 2019

Orchids belong to the largest family of angiosperms possessing the antimicrobial, antioxidant, hepatoprotective, anti-inflammatory, anti-arthritic and wound healing properties revealed in preclinical studies. The study of orchids also can provide health professionals with alternative, feasible, and low-cost therapies for treating bacterial and fungal diseases. For this reason, orchids may be used as new antimicrobial agents. Our previous study reported that the selected orchids belonging to the genus Coelogyne Lindl. exhibited fairly strong antioxidant and antimicrobial activities. This paper focused on the assessment of the antibacterial activity of eight plants, i.e. Coelogyne cristata Lindl., C. fimbriata Lindl., C. flaccida Lindl., C. huettneriana Rchb.f., C. ovalis Lindl., C. speciosa (Blume) Lindl., C. tomentosa Lindl. and C. viscosa Lindl. towards clinical cefuroxime-resistant Enterobacter cloacae strain. Antibacterial activity was evaluated qualitatively and quantitatively using disc diffusion assay. The ethanolic extracts obtained from leaves and pseudobulbs of five orchids belonging to the Coelogyne genus were found to exhibit fairly strong antibacterial activity towards Enterobacter cloacae strain used, the diameter of inhibition zones varied from 8.0-25.5 mm. It has been observed that ethanolic extract obtained from pseudobulbs of eight species from the Coelogyne genus revealed the highest antibacterial activity $(11.0-25.5 \mathrm{~mm}$ as the diameter of inhibition zone) as compared to ethanolic extracts obtained from leaves of the same Coelogyne species. These findings provide a clear demonstration of the generally overlooked importance of the collection of tropical plants accumulated at the Botanic Gardens, orchids collection, in particular, as an important source of new chemical substances with potential therapeutic effects, including antifungal activity. Further studies aimed at the isolation and identification of active substances from the extracts obtained from leaves and pseudobulbs of Coelogyne species could also disclose compounds with better therapeutic value. It is believed that screening of all the investigated plants for other biological activities is essential.

Keywords: orchids, leaf extracts, Enterobacter cloacae, antibacterial activity, disc diffusion technique, ethanolic extracts

\footnotetext{
*Corresponding author: Halyna Tkachenko, Institute of Biology and Earth Sciences, Pomeranian University in Słupsk, Arciszewski 22b, 76-200 Słupsk, Poland $\triangle$ tkachenko@apsl.edu.pl
} 


\section{Introduction}

Enterobacter cloacae are part of the normal flora of the gastrointestinal tract of 40 to $80 \%$ of people and are widely distributed in the environment. Species of the genus Enterobacter are opportunistic pathogens and are capable of causing opportunistic infections in hospitalized patients (intensive care units, emergency units, urology department) (Michalska and Gospodarek, 2007). Species of the Enterobacter cloacae complex are widely encountered in nature (Mezzatesta et al., 2012). Enterobacter aerogenes and E. cloacae have been reported as important opportunistic and multidrug-resistant bacterial pathogens for humans during the last three decades in hospital wards. These Gram-negative bacteria have been largely described during several outbreaks of hospital-acquired infections (Davin-Regli et al., 2015). In recent years, Enterobacter cloacae have emerged as an important nosocomial pathogen (Dalben et al., 2008). The biochemical and molecular studies on E. cloacae have shown genomic heterogeneity, comprising six species: Enterobacter cloacae, Enterobacter asburiae, Enterobacter hormaechei, Enterobacter kobei, Enterobacter ludwigii, and Enterobacter nimipressuralis. E. cloacae and E. hormaechei are the most frequently isolated in human clinical strains (Mezzatesta et al., 2012). The dissemination of Enterobacter spp. is associated with the presence of redundant regulatory cascades that efficiently control the membrane permeability ensuring the bacterial protection and the expression of detoxifying enzymes involved in antibiotic degradation and inactivation. In addition, these bacterial species are able to acquire numerous genetic mobile elements that strongly contribute to antibiotic resistance. Moreover, this particular fitness helps them to colonize several environments and hosts and rapidly and efficiently adapt their metabolism and physiology to external conditions and environmental stresses (Davin-Regli et al., 2015). They are capable of overproducing AmpC $\beta$-lactamases by de-repression of a chromosomal gene or by the acquisition of a transferable ampC gene on plasmids conferring the antibiotic resistance (Mezzatesta et al., 2012).

It has been highlighted that the pathogenic mechanisms and factors contributing to the disease associated with the E. cloacae complex are not understood yet (Davin-Regli et al., 2015). Nevertheless, it was assumed that an ability of E. cloacae to form biofilms and to secrete various cytotoxins (enterotoxins, hemolysins, pore-forming toxins) is important for its pathogenicity (Mezzatesta et al., 2012). Moreover, certain Enterobacter spp. have been reported as plant-growth enhancers since they possess multiple growth-promoting activities (Ramesh et al., 2014).

Plant-derived antimicrobial agents have received much attention due to their effectiveness against drug-resistant strains, and diverse antimicrobial activities including antibiofilm activity (Khan et al., 2017; Lu et al., 2019).

A wide range of phytochemicals has been reported as antibacterial compounds, belonging to different classes, such as alkaloids, terpenoids, polyphenols, tannins, and phenanthrenes. It was emphasized that among them, phenanthrenes are a relatively uncommon class of aromatic metabolites in the plant kingdom, which are mainly found in the Orchidaceae and Juncaceae (Kovács et al., 2008; Chen et al., 2018; Tóth et al., 2018). 
Although the antimicrobial activity of many orchid species, including Coelogyne species, has been effectively established against a wide spectrum of microorganisms (Kovács et al., 2008; Haque and Ghosh, 2015; Chen et al., 2018), bacterial drug resistance continues to be a worldwide public health issue in the treatment of infectious diseases, thereby stimulating search for new alternatives with fewer side effects (Mambe et al., 2019).

The orchid genus Coelogyne Lindl. comprises over 200 species, distributed from Southeast Asia to the south-western Pacific Islands (Clayton, 2002; Chen and Clayton 2009). It is currently divided into 4 subgenera and 19 sections (Gravendeel, 2005). Coelogyne species grow in the primary forest from sea level up to 4,000 m altitude. They are predominantly epiphytes, but in humid environments, some species can grow as lithophytes over rocky cliffs or even as terrestrials (Clayton, 2002). The Coelogyne genus is characterized by sympodial growth habit, pseudobulbs of one internode, a winged column, and massive caudicles (Dressler, 1981). Within Coelogyninae subtribe this genus is distinguished by a free, never-saccate lip, with high lateral lobes over the entire length of the hypochile and smooth, papillose, toothed or warty keels on the epichile (Seidenfaden and Wood 1992).

Correspondingly, taking into consideration the development of resistance by Gram-negative bacteria the present study was aimed to compare the antibacterial activity of the leaf and pseudobulb extracts of eight orchid species, i.e. Coelogyne cristata Lindl., C. fimbriata Lindl., C. flaccida Lindl., C. huettneriana Rchb.f., C. ovalis Lindl., C. speciosa (Blume) Lindl., C. tomentosa Lindl. and C. viscosa Lindl. against clinical cefuroxime-resistant Enterobacter cloacae strain.

\section{Materials And Methodology}

\section{Collection of Plant Material}

The leaves and pseudobulbs of orchids, i.e. C. flaccida Lindl., C. huettneriana Rchb.f., C. speciosa (Blume) Lindl., C. fimbriata Lindl., C. tomentosa Lindl., C. ovalis Lindl., C. cristata Lindl., C. viscosa Rchb.f. (Figure 1) cultivated under glasshouse conditions, were sampled at M.M. Gryshko National Botanic Garden (Kyiv, Ukraine). Since 1999 the whole collection of tropical and subtropical plants (including orchids) has had the status of a National Heritage Collection of Ukraine and is supported through State funding. Besides, M.M. Gryshko National Botanic Garden collection of tropical orchids was registered at the Administrative Organ of CITES in Ukraine (Ministry of Environment Protection, registration No. 6939/19/1-10 of 23 June 2004).

\section{Preparation of Plant Extracts}

The collected leaves and pseudobulbs were brought into the laboratory for antimicrobial studies. Freshly crushed leaves and pseudobulbs were washed, weighed, and homogenized in $96 \%$ ethanol (in proportion $1: 19$ ) at room temperature. The extracts were then filtered and investigated for their antimicrobial activity. 

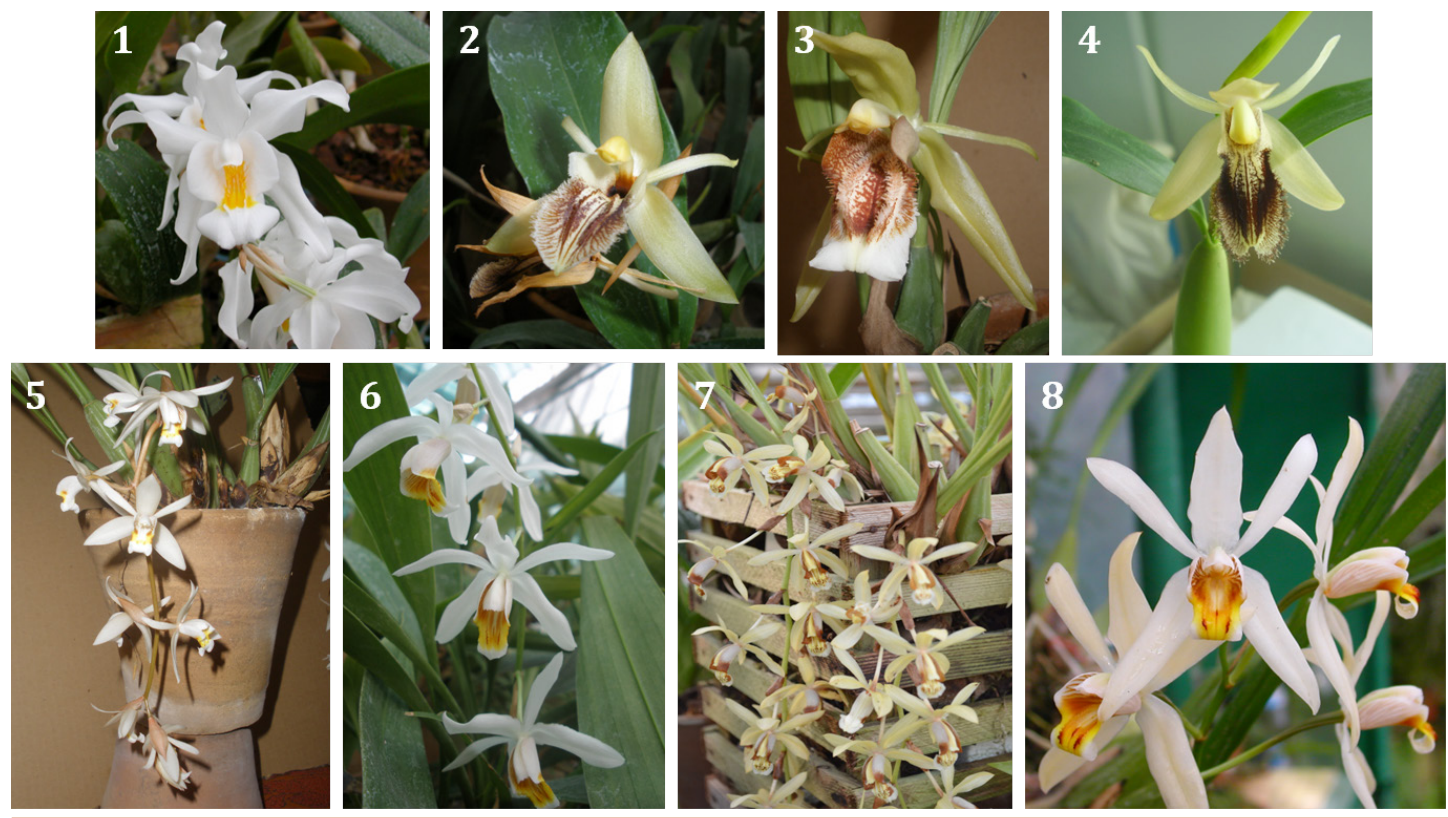

Figure 1

The general views of flowers of Coelogyne species from the collection of M.M. Gryshko National Botanical Garden (Kyiv, Ukraine) (Photo: Lyudmyla Buyun, Oleksandr Gyrenko)

1 - Coelogyne cristata Lindl.; 2 - Coelogyne fimbriata Lindl.; 3 - Coelogyne speciosa (Blume) Lindl.; 4 Coelogyne ovalis Lindl.; 5 - Coelogyne flaccida Lindl.; 6 - Coelogyne huettneriana Rchb.f.; 7 - Coelogyne tomentosa Lindl.; 8 - Coelogyne viscosa Rchb.f.

\section{Bacterial strain}

The testing of the antibacterial activity of the plant extract was carried out in vitro by the Kirby-Bauer disc diffusion technique (Bauer et al., 1966). The non-repetitive clinical strain of cefuroxime-resistant E. cloacae isolated from bloodstream infection was collected from Koszalin Hospital during March-April, 2019. The purity, as well as the identity of isolate, was confirmed in the laboratory conditions by standard microbiological methods and were interpreted according to the guidelines of the Clinical Laboratory Standards Institute (2014).

Susceptibility testing of the isolates was performed by disk diffusion according to the Guidelines of Clinical and Laboratory Standard Institute (CLSI). The antibiotics tested were piperacillin, piperacillin-tazobactam, cefepime, cefotaxime, ceftazidime, cefuroxime, aztreonam, imipenem, meropenem, ertapenem, amikacin, gentamicin, trimethoprimsulphamethoxazole, ciprofloxacin, levofloxacin, tetracycline, tigecycline, and polymyxin B. Results were interpreted according to CLSI criteria. MIC was determined by $E$-test strips (according to manufacturer's instruction) and agar dilution method (according to the Guidelines of Clinical and Laboratory Standard Institute). The resistance breakpoints were the same as the ones defined by the National Committee for Clinical Laboratory Standards (NCCLS, 2014).

Enterobacter cloacae strain studied was resistant to amoxicillin, cefuroxime, trimethoprimsulphamethoxazole, and cefotaxime. 


\section{The Disk Diffusion Method for Evaluation of Antibacterial Activity of Plant Extracts}

Strain tested was plated on TSA medium (Tryptone Soy Agar) and incubated for $24 \mathrm{hr}$ at $37^{\circ} \mathrm{C}$. Then the suspension of microorganisms was suspended in sterile PBS and the turbidity adjusted equivalent to that of a 0.5 McFarland standard. The antimicrobial susceptibility testing was done on Muller-Hinton agar by the disc diffusion method (Kirby-Bauer disk diffusion susceptibility test protocol). Muller-Hinton agar plates were inoculated with $200 \mu \mathrm{l}$ of standardized inoculum (108 CFU/mL) of the bacterium and spread with sterile swabs.

Sterile filter paper discs impregnated by extract were applied over each of the culture plates, 15 min after bacteria suspension was placed. A negative control disc impregnated by sterile $96 \%$ ethanol was used in each experiment. After culturing bacteria on Mueller-Hinton agar, the disks were placed on the same plates and incubated for $24 \mathrm{hr}$ at $37^{\circ} \mathrm{C}$. The assessment of antimicrobial activity was based on the measurement of the diameter of the inhibition zone formed around the disks. The diameters of the inhibition zones were measured in millimeters and compared with those of the control and standard susceptibility disks. The activity was evidenced by the presence of a zone of inhibition surrounding the well.

\section{Statistical analysis}

Zone diameters were determined and averaged. Statistical analysis of the data obtained was performed by employing the mean \pm standard error of the mean (S.E.M.). All variables were randomized according to the phytochemical activity of extracts tested. All statistical calculation was performed on separate data from each extract. The data were analyzed using an one-way analysis of variance (ANOVA) with Statistica software, version 8.0 (StatSoft, Poland) (Zar, 1999). The following zone diameter criteria were used to assign susceptibility or resistance of bacteria to the phytochemicals tested: Susceptible $(S) \geq 15 \mathrm{~mm}$, Intermediate $(I)=10-15 \mathrm{~mm}$, and Resistant $(R) \leq 10 \mathrm{~mm}$ (Okoth et al., 2013).

\section{Results and discussion}

Ethanolic extracts obtained from leaves and pseudobulbs of eight orchids belonging to the Coelogyne genus resulted in considerable suppression of clinical cefuroxime-resistant Enterobacter cloacae strain growth. Moreover, differential efficacy on the test organism was noted between Coelogyne species as well as between extracts obtained from leaves and pseudobulbs tested. Consequently, the extracts from various species displayed varied antibacterial potency against cefuroxime-resistant Enterobacter cloacae (Figure 2, 3).

As presented in Figure 2, tested extracts showed variable antibacterial activities with inhibition zone diameter values ranging from 8.1 to $17.8 \mathrm{~mm}$ (crude extracts derived from the leaves) and from 11.5 to $24.3 \mathrm{~mm}$ (for pseudobulb extracts). In our study, the marked antibacterial efficacy against cefuroxime-resistant Enterobacter cloacae strain was observed in the case of ethanolic extracts obtained from leaves of $C$. tomentosa (mean diameter of inhibition zones was $15.5 \pm 0.9 \mathrm{~mm}), C$. speciosa $(15.9 \pm 0.7 \mathrm{~mm})$, and $C$. huettneriana $(17.8 \pm 1.2 \mathrm{~mm})$. A statistically significant increase $(p<0.05)$ in inhibition zone diameters of strain growth was 
100\% (for C. huettneriana), 79\% (for C. speciosa), and 74\% (for C. tomentosa). Leaf extracts of $C$. cristata, $C$. ovalis, $C$. fimbriata, $C$. viscosa, and $C$. flaccida displayed less inhibitory activity against strain tested (mean diameter of inhibition zones was ranging from 8.0 to $13.5 \mathrm{~mm}$ ) (Figure 2, 3).

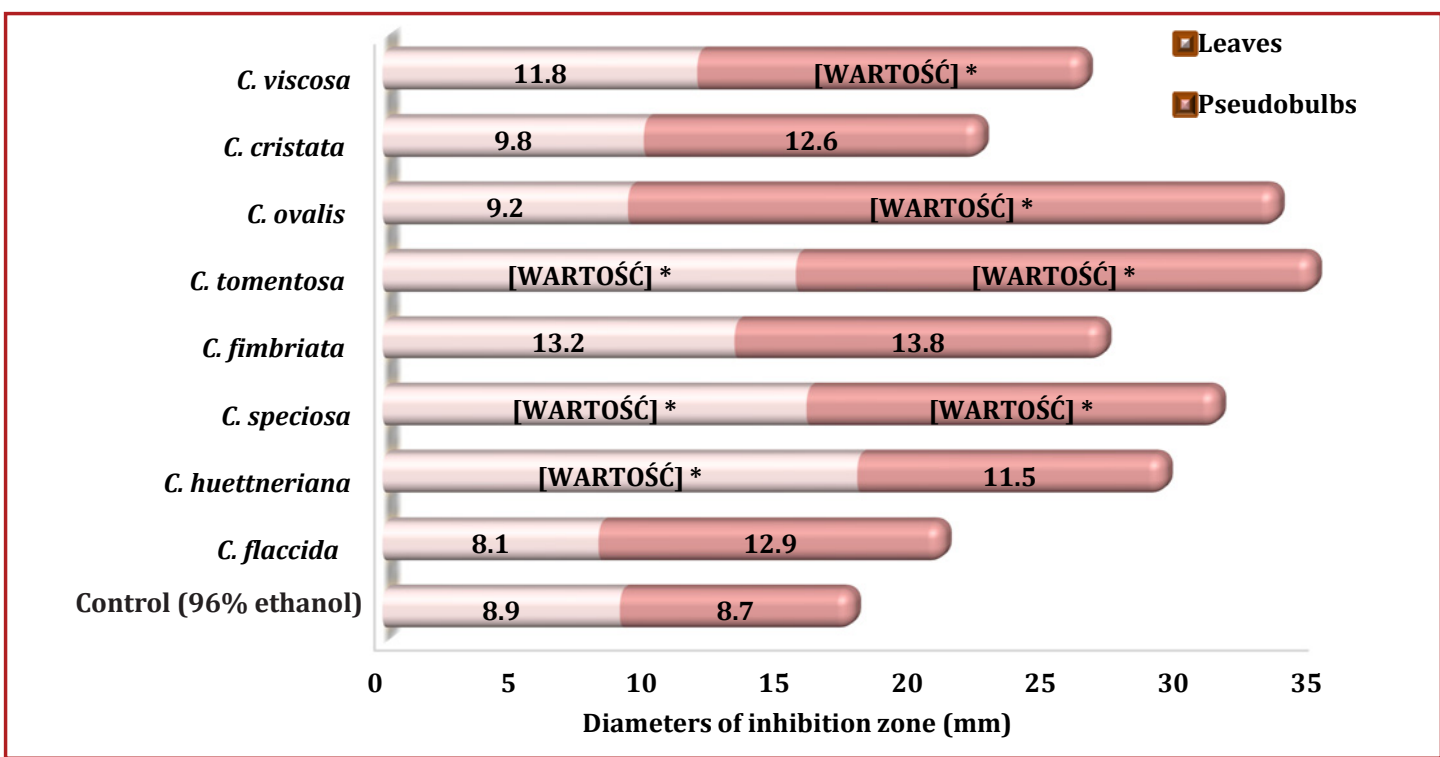

Figure 2 Antimicrobial activity of ethanolic extracts obtained from leaves and pseudobulbs of eight Coelogyne species against cefuroxime-resistant Enterobacter cloacae, measured as diameters of inhibition zone $(n=8)$

On the other hand, the ethanolic extracts obtained from pseudobulbs of $C$. ovalis (mean diameter of inhibition zones was $24.3 \pm 1.3 \mathrm{~mm})$, C. tomentosa $(19.4 \pm 1.1 \mathrm{~mm})$, and $C$. speciosa $(15.4 \pm 0.8 \mathrm{~mm})$ revealed statistically significant antibacterial activity against cefuroximeresistant Enterobacter cloacae strain compared to control (96\% ethanol). A statistically significant increase $(p<0.05)$ in inhibition zone diameters of strain growth was $179 \%$ (for C. ovalis), 123\% (for C. tomentosa), and 77\% (for C. speciosa) (Figure 2, 3).

The present study has shown that ethanolic extracts derived from the leaves and pseudobulbs of eight species from the Coelogyne genus exhibited marked antibacterial activity against Enterobacter cloacae (inhibition zone diameter were ranged from 8.0 to $25.5 \mathrm{~mm}$ ) (Figure 2, 3). Moreover, it has been observed that ethanolic extract obtained from pseudobulbs of eight species from Coelogyne genus revealed the highest antibacterial activity (11.0-25.5 mm as the diameter of inhibition zone) compared to ethanolic extracts obtained from leaves of eight species from Coelogyne genus (Figure 2, 3). 
Buyun, L., Tkachenko, H., Kurhaluk, N., Gyrenko, O., Kovalska, L., Góralczyk, A., Tomin, V., Osadowski, Z. Agr.bio.div. Impr. Nut., Health Life Qual., 2019, 348-360
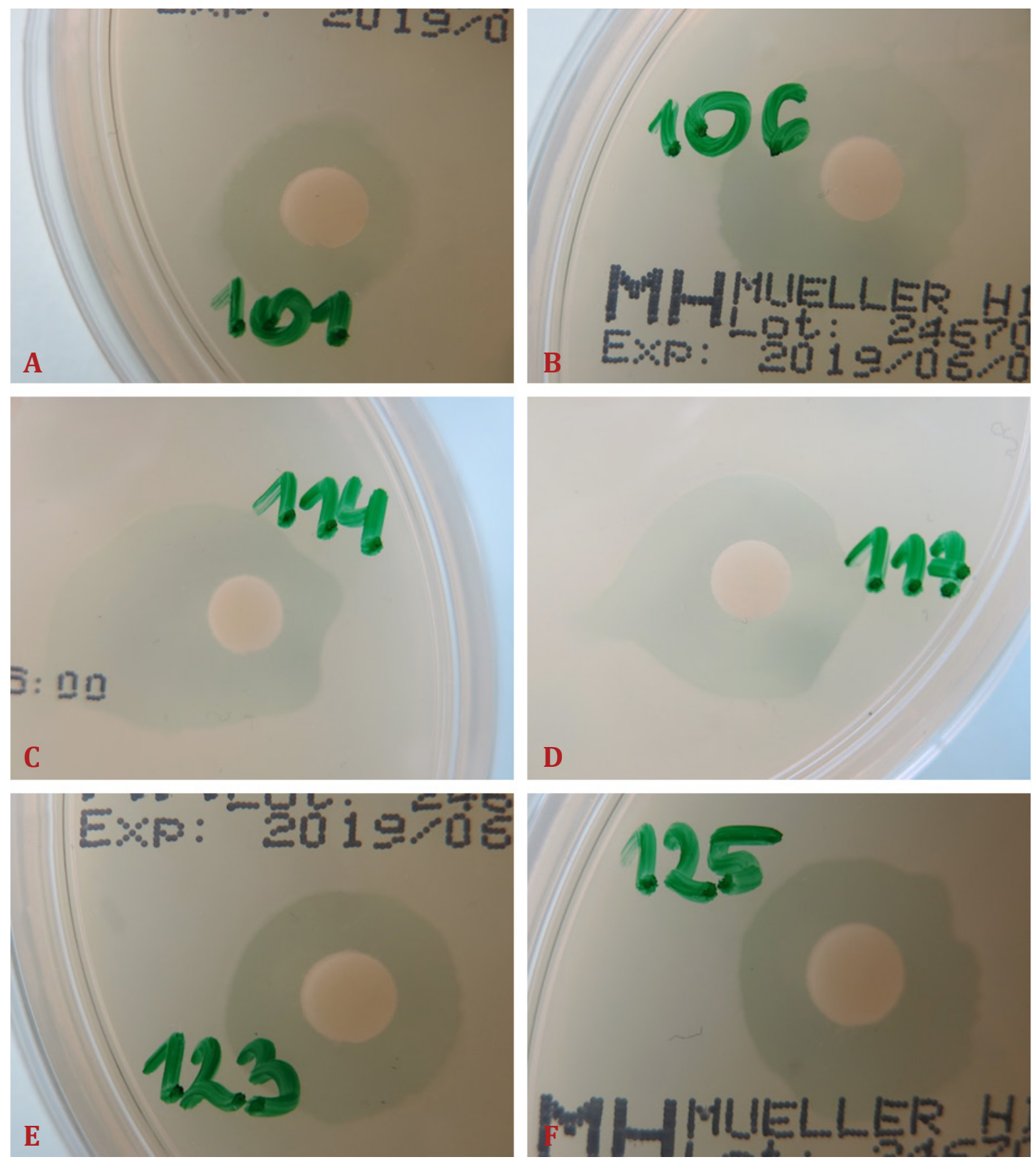

Figure 3 Examples of a disc diffusion assay plate showing the halos in the bacterial lawn resulting from the antibacterial activity of extracts obtained from Coelogyne tomentosa Lindl. leaves (A) and pseudobulbs (B), Coelogyne ovalis Lindl. pseudobulbs (C), Coelogyne huettneriana Rchb.f. leaves (D), Coelogyne speciosa (Blume) Lindl. leaves (E) and pseudobulbs (F)

In recent years, the assessment of antibacterial properties of orchids has received considerable attention (Majumder et al., 1995, 2001, 2011; Singh et al., 2012; Tkachenko et al., 2015; Soumiya and Christudhas, 2017; Buyun et al., 2016, 2017, 2018). A number of orchid species are used as a potent inhibitor against Gram-positive and Gram-negative 
bacteria and also proved to be a potent antimicrobial agent (Singh et al., 2012). Bhatnagar and Ghosal (2018) have conducted phytochemical profiling and evaluation of the antibacterial and antimycobacterial activity of orchid of Arunachal Pradesh, Pleione maculata. The whole plant material was divided into diethyl ether (Et20), n-butanol (n-BuOH) and aqueous (Aq) fractions. The five different MDR bacterial clinical isolates including Escherichia coli (2461), Staphylococcus aureus (2413), Enterococcus sp. (2449), Acinetobacter sp. (2457), Serratia sp. (2442), Mycobacterium tuberculosis H37Rv were used in the study. The screening result identified Et20 fraction as the most active fraction showing significant zone of inhibition against E. coli and Staphylococcus aureus sp. and moderate antimycobacterial activity (MIC value $104.16 \mu \mathrm{g} / \mathrm{mL}$ ) against H37Rv strain of Mycobacterium tuberculosis. The largest zone of inhibition ( $24.1 \pm 0.3$ and $20.7 \pm 0.5 \mathrm{~mm}$ ) was demonstrated by the Et20 fraction against E. coli and $S$. aureus sp. while in case of $\mathrm{n}-\mathrm{BuOH}$ fraction the zone of inhibition was $18.7 \pm 0.7 \mathrm{~mm}$ and $17.1 \pm 0.6 \mathrm{~mm}$ against $S$. aureus and Serratia sp. respectively. However, the aqueous extract was not as effective against any bacterial pathogens as compared to organic solvent fractions even though slight antibacterial activity was observed. The Et20 fraction also inhibited the growth of Serratia sp. and Enterococcus with an inhibition zone $15.2 \pm 0.5 \mathrm{~mm}$ and $13.0 \pm 0.5 \mathrm{~mm}$. The Acinetobacter sp. was least inhibited by the plant fractions. Analysis of the results showed that Et20 fraction of $P$. maculata exhibited moderate antimycobacterial activity against H37Rv strains with MIC $104.16 \mu \mathrm{g} / \mathrm{mL}$ followed by $\mathrm{n}-\mathrm{BuOH}$ fraction with MIC value $166.66 \mu \mathrm{g} / \mathrm{mL}$ respectively. However, the aqueous residue of the plant did not show any activity against Mycobacterium tuberculosis strain. Phytochemical screening of the fractions revealed the presence of triterpenes, phlobatannins, alkaloids and cardiac glycosides in the most active Et20 fraction (Bhatnagar and Ghosal, 2018).

It was shown that blestriacin, a dihydro-biphenanthrene, extracted from the fibrous roots of Bletilla striata exhibited significantly anti-Gram-positive bacterial activity against S. aureus, S. epidermidis, Enterococcus faecalis, and Bacillus subtilis (Qian et al., 2015)

Phytochemical analysis revealed the presence of alkaloids, flavonoids, glycosides, phenols, saponins, sterols in the hydro-alcoholic extract of Coelogyne cristata (Mitra et al., 2018). This orchid species is traditionally used in Indian subcontinent as a stimulant and tonic in aged patients suffering from persistent diseases, like asthma, degenerative changes and bloodborne diseases (Kumari et al., 1986; Singh et al., 2012; Mitra et al., 2018).

Soumiya and Christudhas (2017) have determined the phytochemical screening and antimicrobial activity of Cymbidium aloifolium (L.) Sw. orchids in Kanyakumari district of South India. The phytochemical screening and antimicrobial activity were performed using different extracts (methanol, ethanol, chloroform, acetone and aqueous) of C. aloifolium. Four different bacteria (Gram-positive: Staphylococcus aureus and Bacillus subtilis; Gramnegative: Escherichia coli and Klebsiella pneumoniae) and two fungi (Penicillium sp. and Aspergillus niger) were used in the Soumiya and Christudhas (2017) study. All the extracts showed different degrees of inhibitory action that potential against tested bacteria under this study. The antibacterial activity of $C$. aloifolium leaf extract revealed that the maximum inhibition zone of $34 \mathrm{~mm}$ recorded in aqueous extract against $S$. aureus. Minimum inhibitory activity was recorded in acetone and chloroform extract. The aqueous extract had the highest 
activity against Aspergillus niger and Rhizopus with an inhibition zone of 45 and $42 \mathrm{~mm}$, respectively. Minimum inhibitory activity was recorded in acetone and chloroform extract. The antimicrobial activity of $C$. aloifolium leaf extract revealed that the maximum inhibition zone of ( $43.5 \pm 0.84)$ recorded in aqueous extract against Rhizopus sp. followed by Aspergillus niger ( $42 \pm 0.62)$. The aqueous extract showed the inhibitory activity of $(34.5 \pm 0.40)$ against Staphylococcus aureus. Methanol extract also exhibited some activity against Staphylococcus aureus (30 \pm 0.23$)$ and Klebsiella pneumonia $(25 \pm 0.47)$. The next activity was noticed in ethanol extract against Bacillus subtilis, Aspergillus niger, Klebsiella pneumonia, and Staphylococcus aureus. No activity was noticed in ethanol extract against Escherichia coli and Rhizopus sp. The acetone extract showed significant activity against Bacillus subtilis, Aspergillus niger, and Rhizopus sp. Among the different extracts, aqueous extracts showed better results than the positive control. Minimum inhibitory activity was recorded in methanol extract and acetone extracts (Soumiya and Christudhas, 2017).

The antimycobacterial, leishmanicidal and antibacterial activity of three orchids Rhynchostylis retusa (L.) Blume, Tropidia curculigoides Lindl. and Satyrium nepalense D. Don, traditionally used in tuberculosis, asthma and cold stage of malaria in folk Indian medicine, was demonstrated in the Bhatnagar et al. (2017) study. The dried material of each plant was divided into three parts. Solvent extraction and fractionation afforded altogether 30 extracts and fractions, which were evaluated against Mycobacterium tuberculosis (H37Rv and MDR strain) for antimycobacterial activity; promastigotes and amastigotes of Leishmania donovani for leishmanicidal activity and two Gram-positive and three Gram-negative clinical isolates for antibacterial activity. The most significant antimycobacterial activity was observed with n-hexane fraction of the flower of Satyrium nepalense with MIC of $15.7 \mu \mathrm{g} / \mathrm{mL}$. The most promising leishmanicidal activity was observed with diethyl ether fraction of the roots of Rhynchostylis retusa with $\mathrm{IC}_{50}$ values of 56.04 and $18.4 \mu \mathrm{g} / \mathrm{mL}$ against promastigotes and intracellular amastigotes respectively. Evaluation of antibacterial activity identified $S$. nepalense flower n-hexane and $R$. retusa roots diethyl ether as potential fractions with MIC values of $\leq 100 \mu \mathrm{g} / \mathrm{mL}$ against selected clinical isolates. $S$. nepalense as the most promising plant followed by $R$. retusa and T. curculioides was demonstrated. Also, the fractions exhibited cell cytotoxicity well within the permissible limit (Bhatnagar et al., 2017).

Nagananda and Satishchandra (2013) have evaluated the antibacterial and antifungal activity of medicinally important orchid Dendrobium nodosum Dalzell (syn. Flickingeria nodosa (Dalz.) Seidenf) against human pathogens with cold and hot successive extracts. The antimicrobial activities of the plant extracts were evaluated against 7 bacterial and 6 fungal strains using well diffusion method on Mueller-Hinton agar medium. The cold water extract has antibacterial activity against $S$. aureus and $S$. citreus with a maximum zone of inhibition. The cold chloroform extract has good antifungal activity against T. mentagrophytes (Nagananda and Satishchandra, 2013).

Previously, we have given considerable attention to evaluation of the antibacterial effects of ethanolic extracts obtained from leaves and pseudobulbs of plants belonging to various Coelogyne species, maintained under glasshouse conditions. For example, the assessment of antifungal potential of the leaves of eight orchid species, i.e. Coelogyne cristata, C. fimbriata, 
C. flaccida, C. huettneriana, C. ovalis, C. speciosa, C. tomentosa and C. viscosa against fungus strain, Candida albicans was conducted by Buyun et al. (2018). Marked antifungal efficacy was observed in case of ethanolic extracts derived from leaves of $C$. flaccida (mean diameter of inhibition zones was $19.5 \mathrm{~mm})$, C. viscosa (18.6 mm), C. huettneriana (18.2 mm), and C. fimbriata $(17.5 \mathrm{~mm})$. Extracts of C. cristata, C. ovalis, and C. tomentosa displayed less pronounced inhibitory activity against test fungus (mean diameter of inhibition zones ranging from 16.0 to $17.5 \mathrm{~mm}$ ). Similarly, the ethanolic extracts from the pseudobulbs of eight Coelogyne species exhibited strong activity against $C$. albicans (inhibition zone diameter ranged from 16.0 to $23.5 \mathrm{~mm}$ ). Moreover, it has been observed that ethanolic extract obtained from pseudobulbs of $C$. speciosa revealed the highest antibacterial activity $(21 \mathrm{~mm}$ as diameter of inhibition zone) among various Coelogyne species screened. The results also indicate that scientific studies carried out on medicinal plants having traditional claims of effectiveness might warrant fruitful results (Buyun et al., 2018).

In vitro antimicrobial activity of various extracts obtained from vegetative parts of Coelogyne speciosa against Gram-positive (Staphylococcus aureus ATCC 25923) and Gram-negative bacteria (Escherichia coli ATCC 25922) was also demonstrated in our study (Buyun et al., 2016, 2017). The ethanolic extracts from leaves and pseudobulbs of $C$. speciosa exhibited strong activity against $S$. aureus (inhibition zone diameter was 19.0 and $21.5 \mathrm{~mm}$, respectively), while the methanolic extract from leaves and pseudobulbs revealed mild activity ( 8.0 and 8.0 $\mathrm{mm}$ ). Moreover, it has been observed that ethyl acetate, hexane and dichloromethane extracts obtained from leaves and pseudobulbs of $C$. speciosa displayed no antibacterial activity against $S$. aureus. Our results also showed that ethanolic extract from leaves of $C$. speciosa exhibited strong activity against $E$. coli (inhibition zone diameter was $21 \mathrm{~mm}$ ), while others extract from pseudobulbs revealed minimum activity (inhibition zone diameter did not exceed 12 $\mathrm{mm}$ ). Those extracts in ethyl acetate, hexane, and dichloromethane both from the leaves and pseudobulbs revealed no antibacterial activity against S. aureus (Buyun et al., 2016, 2017).

Finally, the Global Strategy for Plant Conservation (GSPC) outlines 16 targets encompassing knowledge, conservation, sustainable use, awareness, and capacity-building activities at Botanic Gardens (Mounce et al., 2017). Therefore, our recent works have exemplified the conviction that living plant collections accumulated at Botanic Gardens as germplasm repositories, are able to provide great opportunities for multi-focused approach, aimed at both ex situ biodiversity conservation and pharmacological screening as well (Tkachenko et al., 2015, 2018; Buyun et al., 2018). Consequently, we believe that our activity could be considered as an implementation of the Global Strategy for Plant Conservation.

\section{Conclusions}

In conclusion, this study has provided informative data about the antimicrobial potential of the tested plant extracts by suggesting that ethanolic extracts derived from the leaves and pseudobulbs of eight species from Coelogyne genus exhibited marked antibacterial activity against Enterobacter cloacae (inhibition zone diameter ranged from 8 to $25.5 \mathrm{~mm}$ ). Moreover, it has been observed that ethanolic extract obtained from pseudobulbs of eight species from Coelogyne genus revealed the highest antibacterial activity (11.0-25.5 mm as the diameter of 
inhibition zone) as compared to ethanolic extracts obtained from leaves of eight Coelogyne species. Consequently, the present study, which revealed the antibacterial properties of the plant extracts, is a justification of the use of orchids belonging to Coelogyne genus to treat some of the infectious diseases caused by antibiotic-resistant Enterobacter cloacae strains. This fact is withstood by the bactericidal effect of the extracts derived from the leaves and pseudobulbs. Nevertheless, there is still room for an in-depth investigation, in order to make these plants best use in medicine and veterinary and to select them as an alternative to combat bacterial resistance

\section{Acknowledgments}

This study was carried out during the Scholarship Program supported by The Polish National Commission for UNESCO in the Institute of Biology and Earth Sciences, Pomeranian University in Slupsk (Poland). We thank The Polish National Commission for UNESCO for supporting our study.

\section{References}

BAUER, A.W., KIRBY, W.M., SHERRIS, J.C., TURCK, M. 1966. Antibiotic susceptibility testing by a standardized single disk method. In Am. J. Clin. Pathol., vol. 45(4), p. 493-496.

BHATNAGAR, M., GHOSAL, S. 2018. Antibacterial and antimycobacterial activity of medicinal orchid of Arunachal Pradesh. In J. Pharm. Sci. Res., vol. 9(2), p. 712-717. http://dx.doi.org/10.13040/ IJPSR.0975-8232.9(2)

BHATNAGAR, M., SARKAR, N., GANDHARV, N., APANG, O., SINGH, S., GHOSAL, S. 2017. Evaluation of antimycobacterial, leishmanicidal and antibacterial activity of three medicinal orchids of Arunachal Pradesh, India. In BMC Complement. Altern. Med., vol. 17(1), p. 379. http://dx.doi.org/10.1186/ s12906-017-1884-Z

BUYUN, L., GAIDARZHY, M., PROKOPIV, A. 2018. Living collections of tropical plants as National Heritage Collections of Ukraine. In Book of Abstracts of 8th EUROGARD Congress "Botanic Gardens, People and Plants for a Sustainable World" (Lisbon, 7-11 May 2018). Lisbon, p. 81-82.

BUYUN, L., TKACHENKO, H., OSADOWSKI, Z., GÓRALCZYK, A., KOVALSKA, L., GYRENKO, O. 2016. Antimicrobial screening of the various extracts derived from the leaves and pseudobulbs of Coelogyne speciosa (Blume) Lindl. (Orchidaceae). In Słupskie Prace Biologiczne, vol. 13, p. 37-54.

BUYUN, L., TKACHENKO, H., OSADOWSKI, Z., GÓRALCZYK, A., KOVALSKA, L., GYRENKO, O. 2018. Evaluation of antifungal efficacy of ethanolic extracts obtained from vegetative organs of some epiphytic orchids from Coelogyne Lindl. genus against Candida albicans. In Słupskie Prace Biologiczne, vol. 15, p. 39-58.

BUYUN, L., TKACHENKO, H., OSADOWSKI, Z., KOVALSKA, L., GYRENKO, O. 2017. The antimicrobial properties of the various extracts derived from the pseudobulbs of Coelogyne speciosa (Blume) Lindl. (Orchidaceae) against Staphylococcus aureus. In Agrobiodiversity for improving nutrition, health, and life quality, vol. 1, p. 43-49. http://dx.doi.org/10.15414/agrobiodiversity.2017.2585-8246.43-49

CHEN, B.C., LIN, C.X., CHEN, N.P., GAO, C.X., ZHAO, Y.J., QIAN, C.D. 2018. Phenanthrene antibiotic targets bacterial membranes and kills Staphylococcus aureus with a low propensity for resistance development. In Front Microbiol., vol. 9, p. 1593. http://dx.doi.org/10.3389/fmicb.2018.01593

CHEN, S.C., CLAYTON, D. 2009. Coelogyne Lindley. In Wu Z.Y., Raven P.H., Hong D.Y. (Eds). Flora of China (Vol. 25). Science Press, Beijing and Missouri Botanical Garden Press, St. Louis, p. 315-325.

CLAYTON, D. 2002. The genus Coelogyne: a synopsis. Natural History Publications, Kota Kinabalu, p. 316. 
CLSI, 2014. Performance Standards for Antimicrobial Susceptibility Testing. Clinical and Laboratory Standards Institute, Wayne, PA, USA, p. 24.

DALBEN, M., VARKULJA, G., BASSO, M., KREBS, V.L., GIBELLI, M.A., VAN DER HEIJDEN, I., ROSSI, F., DUBOC, G., LEVIN, A.S., COSTA, S.F. 2008. Investigation of an outbreak of Enterobacter cloacae in a neonatal unit and review of the literature. In J. Hosp. Infect., vol. 70(1), p. 7-14. http://dx.doi.org/10.1016/j. jhin.2008.05.003

DAVIN-REGLI, A., PAGÈS, J.M. 2015. Enterobacter aerogenes and Enterobacter cloacae; versatile bacterial pathogens confronting antibiotic treatment. In Front Microbiol., vol. 6, p. 392. http://dx.doi. org/10.3389/fmicb.2015.00392

DRESSLER, R.L. 1981. Subtribus Coelogyninae. In Die Orchideeen, Biologie und Systematik der Orchidaceae. Eugen Ulmer Verlag, Stuttgart, Germany, p. 252-253.

GRAVENDEEL, B. 2005. Coelogyne. In Pridgeon A.M., Cribb P.J., Chase M.W., Rasmussen F.N. (Eds) Genera Orchidacearum, vol. 4. Epidendroideae (Part one). Oxford University Press, Oxford, p. 44-51.

HAQUE, S.M., GHOSH, B. 2017. Regeneration of Cytologically Stable Plants Through Dedifferentiation, Redifferentiation, and Artificial Seeds in Spathoglottis plicata Blume. (Orchidaceae). In Horticultural Plant Journal, vol. 3(5), p. 199-208. https://doi.org/10.1016/j.hpj.2017.10.002

KHAN, I., BAHUGUNA, A., KUMAR, P., BAJPAI, V.K., KANG, S.C. 2017. Antimicrobial Potential of Carvacrol against Uropathogenic Escherichia coli via Membrane Disruption, Depolarization, and Reactive Oxygen Species Generation. In Front Microbiol., vol. 8, p. 2421. http://dx.doi.org/10.3389/ fmicb.2017.02421

KOVÁCS, A., VASAS, A., HOHMANN, J. 2008. Natural phenanthrenes and their biological activity. In Phytochemistry, vol. 69(5), p. 1084-1110. http://dx.doi.org/10.1016/j.phytochem.2007.12

KUMARI, H., PUSHPAN, R., NISHTESWAR, K. 1986. Multi-faceted actions of orchids in ethnomedicine-an appraisal. In J Pharmaceu Biol Arch., vol. 3, p. 996-1002.

LU, L., HU, W., TIAN, Z., YUAN, D., YI, G., ZHOU, Y., CHENG, Q., ZHU, J., LI, M. 2019. Developing natural products as potential anti-biofilm agents. In Chinese Medicine, vol. 14, p. 11. https://doi. org/10.1186/s13020-019-0232-2

MAJUMDER, P.L., BANERJEE, S., MAITI, D.C. 1995. Stilbenoids from the orchids Agrostophyllum callosum and Coelogyne flaccida. In Phytochemistry, vol. 39, p. 649-653. https://doi. org/10.1016/0031-9422(95)00942-Z

MAJUMDER, P.L., BANERJEE, S., PAL, S. 2011. Four new stilbenoids from the orchids Coelogyne ochracea and Coelogyne cristata. In J. Indian Chem. Soc., vol. 88, p. 1293-1304. https://doi.org/10.1002/ chin.201224201

MAJUMDER, P.L., SEN, S., MAJUMDER, S. 2001. Phenanthrene derivatives from the orchid Coelogyne cristata. In Phytochemistry, vol. 58, p. 581-586. https://doi.org/10.1016/S0031-9422(01)00287-4

MAMBE, F.T., NA-IYA, J., FOTSO, G.W., ASHU, F., NGAMENI, B., NGADJUI, B.T., BENG, V.P., KUETE, V. 2019. Antibacterial and antibiotic modifying potential of crude extracts, fractions, and compounds from Acacia polyacantha Willd. against MDR Gram-Negative Bacteria. In Evid. Based Complement. Alternat. Med., vol. 2019, p. 7507549. https://doi.org/10.1155/2019/7507549

MEZZATESTA, M.L., GONA, F., STEFANI, S. 2012. Enterobacter cloacae complex: clinical impact and emerging antibiotic resistance. In Future Microbiol., vol. 7(7), p. 887-902. http://dx.doi. org/10.2217/fmb.12.61

MICHALSKA, A., GOSPODAREK, E. 2007. Enterobacter spp. bacteria - The taxonomy, characteristics, virulence factors and the methods for identification. In Postępy Mikrobiologii, vol. 46(1), p. 39-47.

MISHRA, A.P., SAKLANI, S., SALEHI, B., PARCHA, V., SHARIFI-RAD, M., MILELLA, L., IRITI, M., SHARIFIRAD, J., SRIVASTAVA, M. 2018. Satyrium nepalense, a high altitude medicinal orchid of Indian Himalayan region: chemical profile and biological activities of tuber extracts. In Cell Mol. Biol. (Noisy-le-grand), vol. 64(8), p. 35-43. 
MITRA, A., SUR, T.K., UPADHYAY, S., BHATTACHARYYA, D., HAZRA, J. 2018. Effect of Coelogyne cristata Lindley in alleviation of chronic fatigue syndrome in aged Wistar rats. In J. Ayurveda Integr. Med., vol. 9(4), p. 266-271. http://dx.doi.org/10.1016/j.jaim.2017.06.011

MOUNCE, R., SMITH, P., BROCKINGTON, S. 2017. Ex situ conservation of plant diversity in the world's botanic gardens. In Nat. Plants, vol. 3(10), p. 795-802. https://doi.org/10.1038/ s41477-017-0019-3

NAGANANDA, G.S., SATISHCHANDRA, N. 2013. Antimicrobial activity of cold and hot successive pseudobulb extracts of Flickingeria nodosa (Dalz.) Seidenf. In Pak. J. Biol. Sci., vol. 16(20), p. 1189-1193.

OKOTH, D.A., CHENIA, H.Y., KOORBANALLY, N.A. 2013. Antibacterial and antioxidant activities of flavonoids from Lannea alata (Engl.) Engl. (Anacardiaceae). In Phytochem. Lett., vol. 6, p. 476-481. https://doi.org/10.1016/j.phytol.2013.06.003

QIAN, C.D., JIANG, F.S., YU, H.S., FU, Y.H., CHENG, D.Q., GAN, L.S., et al. 2015. Antibacterial Biphenanthrenes from the fibrous roots of Bletilla striata. In J. Nat. Prod., vol. 78, p. 939-943. http://dx.doi. org/10.1021/np501012n

RAMESH, A., SHARMA, S.K., SHARMA, M.P., YADAV, N., JOSHI, O.P. 2014. Plant growth-promoting traits in Enterobacter cloacae subsp. dissolvens MDSR9 isolated from soybean rhizosphere and its impact on growth and nutrition of soybean and wheat upon inoculation. In Agric. Res., vol. 31, p. 53-66.

SAKEE, U., MANEERAT, S., CUSHNIE, T.P., DE-EKNAMKUL, W. 2011. Antimicrobial activity of Blumea balsamifera (Lin.) DC. extracts and essential oil. In Nat. Prod. Res., vol. 25(19), p. 1849-1856. http://dx.doi.org/10.1080/14786419.2010.485573

SEIDENFADEN, G., WOOD, J.J. 1992. The orchids of peninsular Malaysia and Singapore. In Royal Botanic Gardens, Kew and Botanic Gardens, Singapore. Olsen and Olsen, Fredensborg, Denmark.

SINGH, S., SINGH, A.K., KUMAR, S., KUMAR, M., PANDEY, P.K., SINGH, M.C.K. 2012. Medicinal properties and uses of orchids: a concise review. In Elixir Appl. Bot., vol. 52, p. 11627-11634.

SOUMIYA, G., CHRISTUDHAS, W. 2017. Phytochemical and antimicrobial properties of Cymbidium aloifolium (L.) Sw. leaf. In Indo-Asian Journal of Multidisciplinary Research (IAJMR), vol. 3(2), p. 1103-1109.

TKACHENKO, H., GÓRALCZYK, A., OSADOWSKI, Z., BUYUN, L., GYRENKO, O., KOVALSKA, L. 2018. The antimicrobial potency of ethanolic extract obtained from leaves of Coelogyne brachyptera Rchb. f. (Orchidaceae). In Book of Abstracts of XIV International Scientific Conference for students and Ph.D. students 'Youth and progress of biology', dedicated to the $185^{\text {th }}$ anniversary from the birthday of B. Dybovsky (Ukraine, Lviv, 10-12 April 2018). Lviv, p. 224-226.

TKACHENKO, H., TRUCHAN, M., BUYUN, L., KOVALSKA, L., GYRENKO, A. Antifungal efficacy of some orchids from Coelogyne Lindl. genus against Candida albicans. 2015. In Theses of reports of the International scientific and practical conference of scientists, graduate students, and students 'Integrated protection and quarantine of plants. The prospects of development in XXI century", the National University of bioresources and environmental management of Ukraine (Ukraine, Kyiv, 1920 November 2015). Kyiv, p. 178-181.

TÓTH, B., HOHMANN, J., VASAS, A. 2018. Phenanthrenes: a promising group of plant secondary metabolites. In J. Nat. Prod., vol. 81, p. 661-678. http://dx.doi.org/10.1021/acs.jnatprod.7b00619

ZAR, J.H. 1999. Biostatistical Analysis. $4^{\text {th }}$ ed., Prentice-Hall Inc., Englewood Cliffs, New Jersey. 